(6) OPEN ACCESS

\title{
NMDA receptor binding in focal epilepsies
}

\author{
C J McGinnity, ${ }_{1}^{1,2,3}$ M J Koepp, ${ }^{4,5}$ A Hammers, ${ }^{1,2,3,4,5,6}$ D A Riaño Barros, ${ }^{1,2}$ \\ R M Pressler, ${ }^{7}$ S Luthra, ${ }^{8}$ P A Jones, ${ }^{8}$ W Trigg, ${ }^{8}$ C Micallef, ${ }^{9}$ M R Symms, ${ }^{4,5}$ \\ D J Brooks, ${ }^{1,10}$ J S Duncan ${ }^{4,5}$
}

For numbered affiliations see end of article.

\section{Correspondence to} Professor I S Duncan, Department of Clinical and Experimental Epilepsy, UCL Institute of Neurology, London WC1N 3BG, UK j.duncan@ucl.ac.uk

Received 14 November 2014 Revised 15 April 2015 Accepted 16 April 2015 Published Online First 19 May 2015

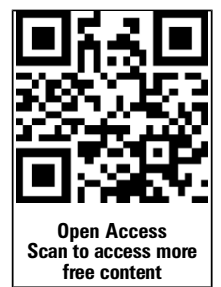

\section{SLinked}

- http://dx.doi.org/10.1136/ jnnp-2015-310333

\section{CrossMark}

To cite: McGinnity CJ, Koepp MJ, Hammers A et al. I Neurol Neurosurg Psychiatry 2015;86: 1150-1157.

\section{ABSTRACT}

Objective To demonstrate altered $\mathrm{N}$-methyl-D-aspartate (NMDA) receptor availability in patients with focal epilepsies using positron emission tomography (PET) and $\left[{ }^{18} \mathrm{~F}\right] \mathrm{GE}-179$, a ligand that selectively binds to the open NMDA receptor ion channel, which is thought to be overactive in epilepsy.

Methods Eleven patients (median age 33 years, 6 males) with known frequent interictal epileptiform discharges had an $\left[{ }^{18} \mathrm{~F}\right] \mathrm{GE}-179$ PET scan, in a crosssectional study. MRI showed a focal lesion but discordant EEG changes in two, was non-localising with multifocal EEG abnormalities in two, and was normal in the remaining seven patients who all had multifocal EEG changes. Individual patient $\left[{ }^{18} \mathrm{~F}\right] \mathrm{GE}-179$ volume-ofdistribution $\left(\mathrm{V}_{T}\right)$ images were compared between individual patients and a group of 10 healthy controls (47 years, 7 males) using Statistical Parametric Mapping. Results Individual analyses revealed a single cluster of focal $V_{T}$ increase in four patients; one with a single and one with multifocal MRI lesions, and two with normal MRIs. Post hoc analysis revealed that, relative to controls, patients not taking antidepressants had globally increased $\left[{ }^{18} \mathrm{~F}\right] \mathrm{GE}-179 \mathrm{~V}_{\mathrm{T}}(+28 \% ; p<0.002)$, and the three patients taking an antidepressant drug had globally reduced $\left[{ }^{18} \mathrm{~F}\right] \mathrm{GE}-179 \mathrm{~V}_{\mathrm{T}}(-29 \% ; \mathrm{p}<0.002)$. There were no focal abnormalities common to the epilepsy group.

Conclusions In patients with focal epilepsies, we detected primarily global increases of $\left[{ }^{18} \mathrm{~F}\right] \mathrm{GE}-179 \mathrm{~V}_{T}$ consistent with increased NMDA channel activation, but reduced availability in those taking antidepressant drugs, consistent with a possible mode of action of this class of drugs. $\left[{ }^{18} \mathrm{~F}\right] \mathrm{GE}-179$ PET showed focal accentuations of NMDA binding in 4 out of 11 patients, with difficult to localise and treat focal epilepsy.

\section{INTRODUCTION}

$\mathrm{N}$-methyl-D-aspartate (NMDA) receptors are ligandgated and voltage-gated ion channels that mediate fast excitatory neurotransmission in the central nervous system (CNS). ${ }^{1} \quad 2 \quad$ NMDA receptormediated neurotransmission is necessary for cognition, memory and neuronal survival, but excessive NMDA receptor activation mediates excitotoxic neuronal injury following acute cerebral insults, ${ }^{3}$ is associated with cell death ${ }^{4}$ and is thought to contribute to disorders of neuronal hyperexcitability, such as epilepsy and neuropathic pain, and chronic neurodegenerative diseases, ${ }^{5}$ depression ${ }^{6} 7$ and schizophrenia. ${ }^{8}$ In chemical models, administration of agonists of either the NMDA or $\alpha$-amino-3- hydroxy-5-methyl-4-isoxazolepropionic acid (AMPA)/ kainate receptors induces convulsions in vivo either by directly mediating an epileptic depolarisation through the NMDA calcium channels or by indirectly activating NMDA channels subsequent to AMPA/kainate receptor activation ${ }^{9-11}$ (for review: ref. 12). Blockade of NMDA receptors is neuroprotective, ${ }^{13}$ prevents paroxysmal depolarisation shifts, which are the intracellular correlate of interictal epileptiform discharges (IEDs) ${ }^{14-17}$ and blocks the development of kindling. ${ }^{18-20}$ Several ${ }^{21} 22$ but not all kindling model studies have shown the presence of increased NMDA receptor availability in the hippocampus and cerebral cortex of epileptic animals. Autoradiography of human epileptogenic temporal lobe tissue has revealed increased NMDA receptor availability in the parahippocampal gyrus, in contrast to decreased availability in the hippocampi, particularly in sclerotic regions. ${ }^{23}{ }^{24}$ In vitro studies in tissue resected from patients with epilepsy have associated NMDA receptor-mediated neurotransmission with epileptic activity. ${ }^{25-30}$ Receptor activation, however, can only be shown in vivo. Human microdialysis studies have revealed marked elevations in extracellular glutamate concentration preceding and during seizures, ${ }^{31-37}$ which would be expected to result in increased NMDA receptor activation. Hence, there is interest in the development of radioligands that allow assessment of NMDA receptor function in humans in vivo.

We have previously observed good brain penetration, moderately heterogeneous distribution in grey matter and suitably rapid washout of the novel NMDA positron emission tomography (PET) tracer $\left[{ }^{18} \mathrm{~F}\right] \mathrm{GE}-179$ in healthy controls. ${ }^{38}$ This ligand binds at the phencyclidine (PCP) recognition site ${ }^{39}$ within the NMDA ion channel pore, and hence requires receptor activation for access. This 'poreblocker' ligand could potentially allow usedependent imaging of the NMDA receptor in the active/open state using PET. We report the first use of $\left[{ }^{18} \mathrm{~F}\right] \mathrm{GE}-179$ PET in focal epilepsies of different focal and multifocal onset. The objective of this proof-of-principle study was to demonstrate in vivo a hypothesised increased NMDA receptor activation in patients with drug-resistant epilepsy.

\section{METHODS}

The study was approved by the Research Ethics Committees of the Royal Marsden Hospital, Imperial College Healthcare NHS Trust and University College London Hospitals NHS 
Foundation Trust. Permission to administer $\left[{ }^{18} \mathrm{~F}\right] \mathrm{GE}-179$ was obtained from the Administration of Radioactive Substances Advisory Committee (ARSAC), UK. All participants provided written, informed consent.

\section{Epilepsy and control populations}

This was a proof-of-principle, cross-sectional pilot study with targets of 12 participants per group. Eleven patients with refractory focal epilepsies (median age 33 years; range 20-50 years; 6 males) were recruited from the outpatient clinics at the National Hospital for Neurology and Neurosurgery. Demographics and clinical details are listed in table 1. Their diagnoses were based on history, seizure semiology, prolonged and repeated interictal and ictal EEG recordings (where available), and MRI data. Patients were chosen who had frequent interictal spikes on previous EEG recordings, which we hypothesised would maximise our chances to detect increased binding to open NMDA receptors. None of the patients were taking an antiepileptic drug (AED) known to act at the NMDA receptor. Exclusion criteria included inability to provide informed consent, claustrophobia, standard MR contraindications, a positive urinary pregnancy test on the day of the PET scan and history of drug abuse. Patient 4, whose seizures consisted of a sustained fluctuation of perception of brightness with pupillary hippus, has been presented in a detailed case report. ${ }^{40}$

The control group, 9 of whom have been described previously, ${ }^{38}$ comprised 10 healthy volunteers without history of neurological or psychiatric illness (median age 46 years; range 25-62 years; 7 males). Additional exclusion criteria were as described for the patients above. A further three seemingly healthy individuals were subsequently excluded; one due to excessive movement throughout the PET scan acquisition, one whose MRI revealed evidence of a cerebral infarct; and one who was discovered to have a history of benzodiazepine abuse. The original control group data were used, rather than repeat imaging; the patient data were acquired at approximately the same time as those of the control group (i.e. within 12 months) using the same imaging protocol.

Median age and body mass index (BMI) were compared between patients and control groups by Mann-Whitney U statistic in SPSS. Gender balance was compared between groups with the (Pearson) $\chi^{2}$ test.

\section{MRI data acquisition}

Three-dimensional volumetric T1-weighted coronal MRI sequences were acquired at Epilepsy Society (Chalfont St. Peter, UK), as previously described. ${ }^{38}$ MRIs were reviewed by an experienced neuroradiologist (CM). MRIs were not available for one control participant, in whom 3.0 T MRI was contraindicated.

\section{EEG}

All patients had an EEG during the PET scan using a Trackit 18/ 8 (Lifelines Limited, Hants, UK) ambulatory EEG recorder and an ECI E1 Cap (Electro-Cap International, Eaton, Ohio, USA) with 19 electrodes placed according to the International 10-20 system. An additional reference electrode (Fpz) was sited just anterior to Fz. The $\mathrm{O} 1$ and $\mathrm{O} 2$ electrodes were removed from the cap prior to scanning for several patients in order to minimise discomfort. The participants were closely observed for evidence of seizures throughout the scan. EEGs were reviewed by an experienced clinical neurophysiologist (RMP). The number of IEDs during the first 30 min of scan acquisition was quantified and correlated with $\left[{ }^{18} \mathrm{~F}\right] \mathrm{GE}-179$ global volume-ofdistribution $\left(\mathrm{V}_{\mathrm{T}}\right)$ using Spearman's r correlation coefficient.

\section{PET image acquisition and data analysis}

PET image acquisition has been described previously. ${ }^{38}$ Briefly, images were acquired using a Siemens/CTI ECAT EXACT3D 962 HR+PET camera (Siemens, Erlangen, Germany) at Hammersmith Imanet Limited. Each participant had a $90 \mathrm{~min}$ dynamic emission scan with a smooth bolus intravenous injection of median $187 \mathrm{MBq}$ (range 173-192 MBq) [ $\left.{ }^{18} \mathrm{~F}\right] \mathrm{GE}-179$ administered 30 seconds after starting image acquisition. For calculation of continuous decay-corrected and metabolite-corrected parent plasma input functions, discrete arterial blood samples were taken throughout the scan, with continuous arterial blood sampling for the first 15 minutes.

The area under the metabolite model curves $\left(\mathrm{AUC}_{\text {metabs }}\right)$ was used as a measure of the rate of metabolism for each individual. The $\mathrm{AUC}_{\text {metabs }}$ over $\mathrm{t}=0-30$ minutes and $\mathrm{t}=0-90.5$ minutes was compared between groups by multivariate general linear model (GLM), with gender as a fixed factor, and age and BMI as covariates. The residual sum of squares ( $\mathrm{RSS}_{\text {metabs }}$ ) for the metabolite model curve was compared between groups by univariate GLM. The threshold for statistical significance was $\mathrm{p}=0.05$.

The $\mathrm{V}_{\mathrm{T}}$ of $\left[{ }^{18} \mathrm{~F}\right] \mathrm{GE}-179$ was computed at the voxel level for each participant by exponential spectral analysis, as described previously. $^{38}$

Each participant's $\mathrm{V}_{\mathrm{T}}$ image was spatially normalised using a scanner-specific template. To enable group-wise comparisons, images acquired from patients with an epileptogenic zone in the right hemisphere (3 patients) were left-right flipped prior to normalisation; three control participants' images were also leftright flipped prior to group-wise comparison (controls 1, 4 and 6 , selected at random). For individual (1 patient vs 10 controls) comparisons, the native (unflipped) patient and control images were used.

The primary outcome measure, global $\mathrm{V}_{\mathrm{T}}$, was computed as an overall mean over the entire matrix, thresholded at $1 / 8$ of that value to create a brain mask, and averaged again within this mask. The global $\mathrm{V}_{\mathrm{T}}$ values were compared between groups using a univariate GLM, with gender as a fixed factor, and age and BMI as covariates.

In order to identify changes in the regional distribution of activated NMDA receptors, group-wise SPM8 analyses based on the smoothed (12 mm Full Width at Half Maximum (FWHM) isotropic Gaussian kernel), transformed parametric $\mathrm{V}_{\mathrm{T}}$ images, were performed, comparing patients with focal epilepsy against the controls. The images were compared on a voxel-by-voxel basis using a two-sample $t$ test, assuming unequal variances, with global $\mathrm{V}_{\mathrm{T}}$ taken into account via an analysis of covariance (ANCOVA) by group. The images were grey and white matter (explicit) masked, with relative threshold masking at 0.4 . We report differences in $\left[{ }^{18} \mathrm{~F}\right] \mathrm{GE}-179 \mathrm{~V}_{\mathrm{T}}$ at $\mathrm{p}<0.001$ (uncorrected), clusters at $\mathrm{p}<0.05$ (uncorrected) and an extent threshold of 15 voxels.

In order to identify participant-specific changes in the regional distribution of activated NMDA receptors, individual SPM8 analyses based on the smoothed transformed parametric $\mathrm{V}_{\mathrm{T}}$ images were also performed for each of the patients with frequent IEDs against the 10 controls. Equal variances were assumed and global $\mathrm{V}_{\mathrm{T}}$ taken into account via an ANCOVA by group. The unflipped $\mathrm{V}_{\mathrm{T}}$ image for each control participant was compared with those of the nine other controls in an identical fashion. 
Table 1 Patients with focal epilepsy and frequent IED—clinical details

\begin{tabular}{|c|c|c|c|c|c|c|c|c|c|c|c|c|c|c|}
\hline ID & $\begin{array}{l}\text { Age/sex/ } \\
\text { handed- } \\
\text { ness }\end{array}$ & $\begin{array}{l}\text { Probable } \\
\text { localisation } \\
\text { MRI/EEG }\end{array}$ & $\begin{array}{l}\text { Onset/ } \\
\text { duration } \\
\text { (years) }\end{array}$ & $\begin{array}{l}\text { Postictal } \\
\text { interval }\end{array}$ & Treatment & Seizures & EEG & MEG & MRI & $\begin{array}{l}{\left[{ }^{18} \mathrm{~F}\right]} \\
\text { FDG-PET }\end{array}$ & $\begin{array}{l}\text { Global }\left[{ }^{18} \mathrm{~F}\right] \\
\text { GE-179 } \mathrm{V}_{\mathrm{T}}\end{array}$ & $\begin{array}{l}\text { Approximately } \\
\mathrm{N} \text { of observed } \\
\text { IEDs ( } \mathrm{t}=0- \\
30 \mathrm{~min})\end{array}$ & $\begin{array}{l}{\left[{ }^{18} \mathrm{~F}\right] \mathrm{GE}-179 \mathrm{~V}_{\mathrm{T}}} \\
\text { increases }\end{array}$ & $\begin{array}{l}{\left[{ }^{18} \mathrm{~F}\right] \mathrm{GE}-179 \mathrm{~V}_{\mathrm{T}}} \\
\text { decreases }\end{array}$ \\
\hline 1 & $41 / \mathrm{M} / \mathrm{R}$ & L frontal & $14.5 / 26.5$ & $6.0 \mathrm{~h}$ & $\begin{array}{l}\text { CBZ, LEV, } \\
\text { LTG, ZNS }\end{array}$ & $\begin{array}{l}\text { SPS, CPS, } \\
\text { SGS }\end{array}$ & $\mathrm{L}$ frontotemporal & NA & R IFG lesion & $\mathrm{L}$ temporal & 6.16 & 62 & $L$ frontal & \\
\hline 2 & $22 / \mathrm{M} / \mathrm{R}$ & $\mathrm{L}$ temporal & $4 / 18$ & $7.5 \mathrm{~h}$ & CBZ, LEV, LAC & CPS, SGS & $\begin{array}{l}\mathrm{L} \text { frontotemporal } \\
\text { and } \mathrm{R} \text { temporal }\end{array}$ & NA & L HS & $\begin{array}{l}\mathrm{L} \\
\text { hemisphere }\end{array}$ & 7.20 & 43 & & \\
\hline 3 & 38/M/L & $\begin{array}{l}\text { Multifocal } \\
\text { MRI, EEG/ } \\
\text { MEG }\end{array}$ & $2.5 / 36.5$ & $45 \mathrm{~min}$ & $\begin{array}{l}\text { CBZ, CLB, } \\
\text { PHT, TPM, } \\
\text { fexofenadine }\end{array}$ & $\begin{array}{l}\text { SPS, CPS, } \\
\text { SGS }\end{array}$ & $\mathrm{R}$ frontotemporal & $\begin{array}{l}R \text { frontal, } \\
L \text { and } R \\
\text { temporal }\end{array}$ & $\begin{array}{l}\text { Bilateral tubers: } \\
\mathrm{F}, \mathrm{P}, \mathrm{L}-\mathrm{O} \text {, } \\
\text { periventricular calc }\end{array}$ & $\mathrm{R}$ temporal & 8.16 & 0 & & \\
\hline 4 & 28/F/R & $\begin{array}{l}\text { Multifocal } \\
\text { MRI, EEG/ } \\
\text { MEG }\end{array}$ & $10 / 18$ & $20.5 \mathrm{~h}$ & $\begin{array}{l}\text { LEV, } \\
\text { sertraline, } \\
\text { amlodipine }\end{array}$ & $\begin{array}{l}\text { SPS } \\
\text { (pupillary } \\
\text { hippus) }\end{array}$ & $\mathrm{R}$ temporoparietal & $\begin{array}{l}\text { R parieto-occipital } \\
>\mathrm{R} \text { temporal } \\
>\text { L occipital }\end{array}$ & $\begin{array}{l}\text { Bilateral tubers: } \\
\text { L and R frontal, } \\
\text { L temporal, } \\
\text { R parieto-occipital, } \\
\text { L occipital }\end{array}$ & NA & 4.53 & $\begin{array}{l}\text { EEG data } \\
\text { corrupted }\end{array}$ & $\begin{array}{l}\text { Brainstem; } \\
\text { L temporal; } \\
\text { R temporal }\end{array}$ & R parietal \\
\hline 5 & $50 / F / R$ & $\begin{array}{l}\text { MRI negative } \\
\text { Multifocal } \\
\text { EEG/MEG }\end{array}$ & $11 / 39$ & 39 days & $\begin{array}{l}\text { LEV, PHT, } \\
\text { lofepramine }\end{array}$ & CPS SGS & $\mathrm{L}>\mathrm{R}$ temporal & $\begin{array}{l}\mathrm{L} \text { and } \mathrm{R} \\
\text { temporal }\end{array}$ & Neg & L temporal & 5.32 & 26 & $\mathrm{R}$ frontal & \\
\hline 6 & $33 / \mathrm{M} / \mathrm{L}$ & $\begin{array}{l}\text { MRI negative } \\
\text { Unifocal EEG/ } \\
\text { MEG }\end{array}$ & $19 / 14$ & NA & $\begin{array}{l}\text { CLN, RUF, } \\
\text { fluoxetine }\end{array}$ & CPS & L temporal & L frontotemporal & Neg & Neg & 3.90 & 168 & & \\
\hline 7 & $23 / \mathrm{M} / \mathrm{L}$ & $\begin{array}{l}\text { MRI-negative } \\
\text { Unifocal EEG }\end{array}$ & $16 / 7$ & 3 days & CBZ, VAL & SPS, SGS & $R$ frontal & NA & Neg & Neg & 7.72 & 86 & $\begin{array}{l}\text { L frontal; } \\
\text { R frontal }\end{array}$ & $\begin{array}{l}\text { L temporal; R } \\
\text { frontal }\end{array}$ \\
\hline 8 & 40/F/L & $\begin{array}{l}\text { MRI negative } \\
\text { PET/MEG L } \\
\text { Frontal }\end{array}$ & $12.5 / 28$ & 11 days & $\begin{array}{l}\text { CLB, LAC, } \\
\text { OXC }\end{array}$ & SGS & $L>R$ frontal & LF & Neg & $\mathrm{L}$ frontal & 8.40 & 42 & & \\
\hline 9 & $24 / \mathrm{M} / \mathrm{R}$ & $\begin{array}{l}\text { MRI negative } \\
\text { Multifocal } \\
\text { EEG/MEG }\end{array}$ & $7 / 17$ & $6.5 \mathrm{~h}$ & $\begin{array}{l}\text { LAC, LEV, } \\
\text { LTG, OXC, } \\
\text { CLB }\end{array}$ & CPS, SGS & $R$ frontocentral & $\begin{array}{l}\mathrm{L} \text { frontal } \\
>\mathrm{L} \text { insula. } \\
>\mathrm{L} \text { frontotemporal }\end{array}$ & Neg & Neg & 8.44 & 9 & & \\
\hline 10 & 50/F/R & $\begin{array}{l}\text { MRI negative } \\
\text { Multifocal } \\
\text { EEG/MEG }\end{array}$ & $13 / 37$ & 10 +years & LEV, LAC, LTG & CPS & $\mathrm{L}>\mathrm{R}$ temporal & $\mathrm{L}$ and $\mathrm{R} \mathrm{T}$ & Neg & NA & 8.17 & $\begin{array}{l}\text { Cont epileptiform } \\
\text { activity* }^{*}\end{array}$ & & \\
\hline 11 & 20/F/R & $\begin{array}{l}\text { MRI negative } \\
\text { Multifocal } \\
\text { EEG }\end{array}$ & $14 / 6$ & $39.5 \mathrm{~h}$ & CLB, OXC, & CPS, SGS & $\mathrm{R}>\mathrm{L}$ temporal & NA & Neg & $\mathrm{Neg}$ & 8.88 & 3 & & \\
\hline
\end{tabular}

Antidepressant drugs (patients 4-6) are displayed in bold font.

*EEG revealed continuous ongoing focal epileptiform activity in patient 10, who had not shown clinically evident seizure activity within the preceding 10 years. Underline indicates concordance between the cluster of increase and the location of the presumed epileptogenic zone, where known.

Calc, calcification; CBZ, carbamazepine; CLB, clobazam; CLN, clonazepam; CPS, complex partial seizures; EEG, electroencephalography; F, frontal lobe; F/M, female/male; $\left.{ }^{18} \mathrm{~F}\right] \mathrm{FDG}-\mathrm{PET}$, [ $\left.{ }^{18} \mathrm{~F}\right] \mathrm{fluorodeoxyglucose}$ positron emission tomography; HS, hippocampal sclerosis; ID, identifying number; IED, interictal epileptiform discharges; IFG, inferior frontal gyrus; L/R, left/right; LAC, lacosamide; LEV, levetiracetam; LTG, lamotrigine; MEG, magnetoencephalography; MRI, magnetic resonance imagining; NA, not available; Neg, negative, that is, no significant findings; O, occipital; OXC, oxcarbazepine; P, parietal lobe; PHT, phenytoin; RUF, rufinamide; SGS, secondary generalised seizures; SPS, simple partial seizures; TPM, topiramate; VAL, valproate; $V_{T}$, volume-of-distribution; ZNS, zonisamide. 


\section{RESULTS}

There was no difference between patient and control group in terms of age $(p=1.00)$, BMI $(p=1.00)$ or gender mix $(p=0.47)$.

There were no significant differences in the $\mathrm{AUC}_{\text {metabs }}$ or the $\mathrm{RSS}_{\text {metabs }}$ between the groups $(\mathrm{p}=0.19$ and $\mathrm{p}=0.47$, respectively). Age, BMI and gender also did not significantly influence the $\mathrm{AUC}_{\text {metabs }}($ all $\mathrm{p}>0.09$ ).

\section{Global changes in $\mathrm{V}_{\mathrm{T}}$}

Global $\mathrm{V}_{\mathrm{T}}$ was higher in the focal epilepsy group (median 7.51, range 3.77-8.66) than in controls (median 6.21, range 5.377.56), although this did not reach statistical significance $(p=0.40)$. There were two distinct subgroups of patients with higher $(n=8)$ and lower $(n=3)$ than normal global $V_{T}$. To explore this distribution in patients further, post hoc analysis revealed large and significant differences in global $\mathrm{V}_{\mathrm{T}}$ between patients with focal epilepsy who were not taking antidepressant drugs (median 7.97 , range $6.04-8.66$; $+28 \%$ relative to controls), and those who were taking antidepressant drugs (median 4.40 , range $3.77-5.15 ;-29 \%$ relative to controls), and controls (6.21, range 5.37-7.56; all $\mathrm{p}<0.002$; figure 1 ).

There were no differences (in gender, age, $\mathrm{AUC}_{\text {metabs, }}$ $\mathrm{RSS}_{\text {metabs, }}$ BMI, number of IEDs in the first $30 \mathrm{~min}$ postinjection) to explain the occurrence of high- $\mathrm{V}_{\mathrm{T}}$ and low $-\mathrm{V}_{\mathrm{T}}$ patients other than their use of antidepressants.

Frequent IEDs were noted in the EEG of eight patients throughout the first $30 \mathrm{~min}$ of scan acquisition. Global $\mathrm{V}_{\mathrm{T}}$ did not correlate with the frequency of IEDs measured in the first 30 min after radiotracer injection.

In the following analyses, in order to detect focal increases in activated NMDA receptors over and above global increases, the contribution of global $\mathrm{V}_{\mathrm{T}}$ to variance was removed by an ANCOVA by group.

\section{Focal changes-group comparisons}

There were no common areas of relative focal decrease or focal accentuations of the globally increased $\left[{ }^{18} \mathrm{~F}\right] \mathrm{GE}-179 \mathrm{~V}_{\mathrm{T}}$ in the patient group compared with controls.
Relative decreases in $\mathrm{V}_{\mathrm{T}}$-individual comparisons

A focal decrease in $\left[{ }^{18} \mathrm{~F}\right] \mathrm{GE}-179 \mathrm{~V}_{\mathrm{T}}$ was seen in two healthy control participants (control 3 mid-parietal; control 4 frontal pole). A relative focal decrease in $\left[{ }^{18} \mathrm{~F}\right] \mathrm{GE}-179 \mathrm{VT}$ was seen in two patients (table 2). None of these changes reached significance after correction for multiple comparisons. In one patient (patient 10), the area of relatively decreased $V_{T}$ was concordant with one of the multiple tubers seen on MRI.

\section{Relative increases in $\mathrm{V}_{\mathrm{T}}$-individual comparisons}

Focal increases in $\left[{ }^{18} \mathrm{~F}\right] \mathrm{GE}-179 \mathrm{~V}_{\mathrm{T}}$ were seen in one control participant (control 4), maximal in the left parieto-occipital region. A focal increase above global baseline increase in $\left[{ }^{18} \mathrm{~F}\right] \mathrm{GE}-179$ $\mathrm{V}_{\mathrm{T}}$ was seen in four patients (table 3 and figure 2). Where known, the largest cluster was localised to the lobe of the presumed epileptogenic zone in one, as was the second largest cluster of a further two patients.

\section{DISCUSSION}

Using $\left[{ }^{18} \mathrm{~F}\right] \mathrm{GE}-179$ PET, we identified global increases in NMDA receptor ion channel availability for patients with focal epilepsies who were not taking antidepressants, whereas tracer binding was globally decreased in those patients with epilepsy who were also taking antidepressant drugs. Increases in $\left[{ }^{18} \mathrm{~F}\right]$ GE-179 $\mathrm{V}_{\mathrm{T}}$ are consistent with an increase in activated/open NMDA receptors in actively discharging cortex as shown in preclinical work. $^{21} 22$ We suggest that increased NMDA activation in patients with chronic focal epilepsy extends beyond the presumed epileptogenic zone and is a global phenomenon, as reflected in the increased global $\mathrm{V}_{\mathrm{T}}$.

Our group analyses did not identify any focal redistribution of activated NMDA receptor availability in this group of heterogeneous patients with focal epilepsies arising from different cortical locations; this is perhaps not surprising given the heterogeneity and small sample size. For this pilot study, patients were selected based on the frequency of IEDs on previous EEGs, to maximise our chances of detecting increases in NMDA binding. Concordance of $\left[{ }^{18} \mathrm{~F}\right] \mathrm{GE}-179$ foci with EEG, structural and functional imaging in individual patients is difficult to assess

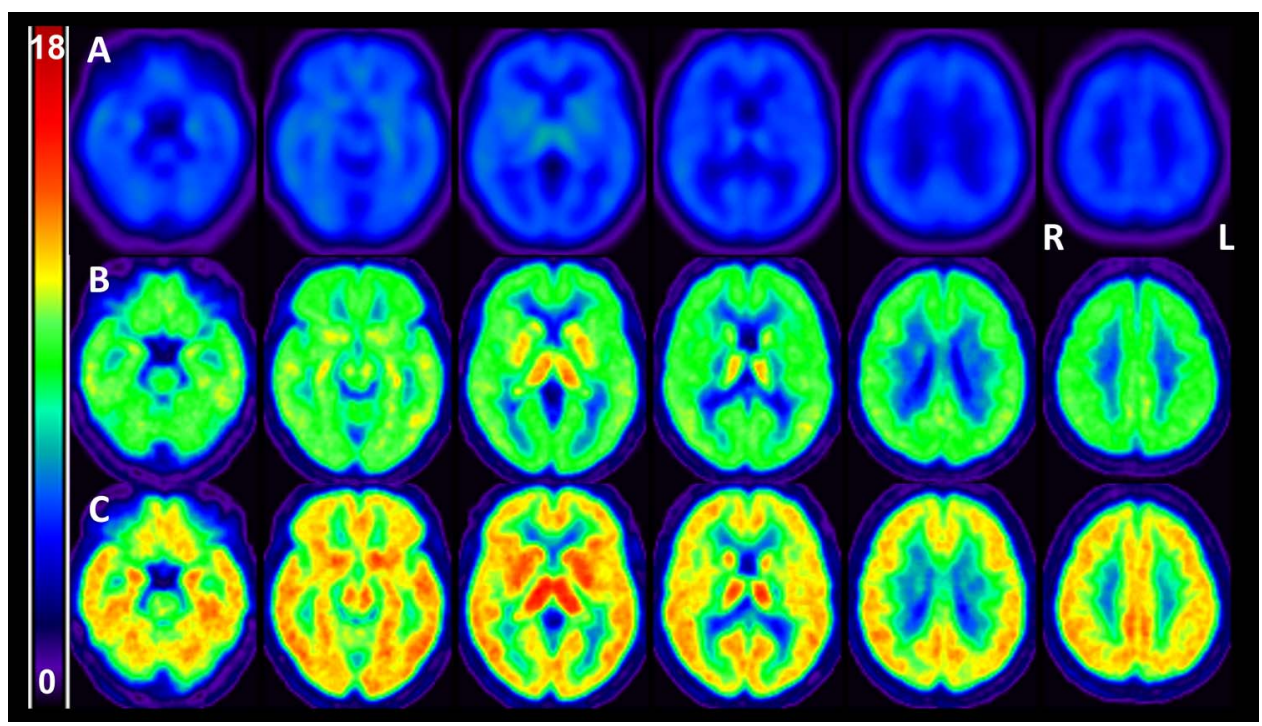

Figure $1 \quad\left[{ }^{18} \mathrm{~F}\right] \mathrm{GE}-179 \mathrm{~V}_{\mathrm{T}}$ by subgroup. The top row $(\mathrm{A})$ depicts the mean $\left[{ }^{18} \mathrm{~F}\right] \mathrm{GE}-179 \mathrm{~V}$ patients with focal epilepsy who were taking an antidepressant drug; the middle row (B) for the controls; and the bottom row (C) for the patients with focal epilepsy who were not taking an antidepressant drug. Images are displayed according to radiological convention (ie, 'left is right'). L, left; $R$, right; $V_{T}$, volume-of-distribution. 
Table 2 Focal decreases in $\left[{ }^{18} \mathrm{~F}\right] \mathrm{GE}-179 \mathrm{~V}_{\mathrm{T}}$-individual patients versus 10 controls

\begin{tabular}{|c|c|c|c|c|c|c|c|}
\hline Patient ID & $\begin{array}{l}\text { Probable } \\
\text { localisation (EEG) }\end{array}$ & MRI & $\begin{array}{l}{\left[{ }^{18} \mathrm{~F}\right] \mathrm{GE}-179} \\
\mathrm{~V}_{\mathrm{T}} \text { decreases }\end{array}$ & $\begin{array}{l}\text { Cluster size } \\
\left(\mathrm{mm}^{3} / \text { voxels }\right)\end{array}$ & $\begin{array}{l}\text { Peak voxel coordinates } \\
(x, y, z ; m m)\end{array}$ & $Z_{\max }$ & $\begin{array}{l}\text { Cluster level } \\
\text { p (uncorrected) }\end{array}$ \\
\hline 4 & Multifocal & Multiple tubers & $\mathrm{R}$ parietal & $4864 / 608$ & $62-3238$ & 3.62 & 0.002 \\
\hline \multirow[t]{2}{*}{7} & $\mathrm{R}$ frontal & Negative & $\mathrm{L}$ temporal & $3968 / 496$ & $-58-20-22$ & 4.32 & 0.003 \\
\hline & & & $R$ frontal & $1704 / 213$ & $1020-20$ & 3.89 & 0.040 \\
\hline
\end{tabular}

The cluster(s) reaching significance at $p<0.05$ uncorrected are listed. The contribution of global $\mathrm{V}_{\mathrm{T}}$ to variance was removed by an ANCOVA by group.

ANCOVA, analysis of covariance; EEG, electroencephalography; ID, identifying number; L/R, left/right; mm, millimeters; MRI, magnetic resonance imaging; $V_{T}$, volume-of-distribution.

given that some of our cohort had normal or EEG-discordant MRI and poorly defined epileptogenic zones: the epileptogenic zone could not be localised using high-resolution MRI, ictal EEG recordings, magnetoencephalography and fluorodeoxyglucose PET (FDG-PET) in four patients, and could only be lateralised to one lobe in four of the remaining seven patients. In contrast, our individual $\left[{ }^{18} \mathrm{~F}\right] \mathrm{GE}-179$ PET analysis identified focal clusters of increased NMDA receptor activation in four patients with focal epilepsy, and these were concordant with the location of the presumed epileptogenic zone in two of those three patients, in whom this could be lateralised to one lobe. Patient 1 was one of the best-localised cases in our cohort, having concordant scalp EEG, $\left[{ }^{18} \mathrm{~F}\right]$ FDG-PET and ictal single-photon emission CT findings. An intracranial EEG recording over the left temporal lobe revealed a diffuse ictal onset, consistent with spread from a nearby lobe. Consistent with these data, a large cluster of increased $\mathrm{V}_{\mathrm{T}}$ was observed in the left frontal lobe for this participant.

Interestingly, a focal increase in $\left[{ }^{18} \mathrm{~F}\right] \mathrm{GE}-179 \mathrm{~V}_{\mathrm{T}}$ was seen in the brainstem of the patient with ictal pupillary hippus in addition to left and right temporal lobe increases (patient $4^{23}$ ). The patient is now seizure-free after resection of the tuber in the right parieto-occipital region. Our finding suggests the unusual ictal manifestation might result from a broad epileptogenic network that encompassed the brainstem in close proximity to the nuclei of the oculomotor (III) nerve.

The proportion of NMDA receptors that are active in the resting physiological state is unknown, and the power to detect subtle regional changes in channel opening superimposed on global differences in binding, induced by the epileptic brain or reduced by concomitant use of antidepressants, was limited by our small sample size and conservative thresholds. Studies of unequivocally unifocal epilepsies are now needed to determine whether focal increases of $\left[{ }^{18} \mathrm{~F}\right] \mathrm{GE}-179$ binding may be apparent at epileptic foci. If these initial findings are replicated, $\left[{ }^{18} \mathrm{~F}\right] \mathrm{GE}-179$ PET might find clinical application in the presurgical localisation of epileptogenic foci in patients with refractory focal epilepsy with non-contributory MRI.

Interictal regional cerebral blood flow ( $\mathrm{rCBF}$ ) studies usually show reduced perfusion in focal epilepsy, ${ }^{41}$ and significant increases in $\mathrm{rCBF}$ scans were only seen with prolonged discharges of $8-105$ seconds after electrostimulation. ${ }^{42}$ Our findings are unlikely to reflect changes in cerebral blood flow (ie, altered $\left[{ }^{18} \mathrm{~F}\right] \mathrm{GE}-179$ availability) as decreased perfusion in the epileptogenic zone would likely result in decreased $\left[{ }^{18} \mathrm{~F}\right] \mathrm{GE}-179$ availability and thus $\mathrm{V}_{\mathrm{T}}$. While NMDA receptor ion channel opening and the excitatory postsynaptic current are extremely rapid events, ${ }^{43}$ grey matter uptake and the metabolism of $\left[{ }^{18} \mathrm{~F}\right] \mathrm{GE}-179$ occurs over minutes. ${ }^{38}$ Hence, we interpret the $\mathrm{V}_{\mathrm{T}}$ data as indicative of the integrated extent of NMDA receptor activation during the tracer uptake phase (first $30 \mathrm{~min}$ ) of the scan.

The lack of focal increases in $\mathrm{V}_{\mathrm{T}}$ for 7 of the 11 patients with focal epilepsy did not appear to relate to the frequency of scalpdetected IEDs. Global $\left[{ }^{18} \mathrm{~F}\right] \mathrm{GE}-179 \mathrm{~V}_{\mathrm{T}}$ was not significantly correlated with the number of IEDs in the first $30 \mathrm{~min}$ following injection. The true extent of epileptic activity will not be detectable on scalp EEG, which may explain the lack of correlation between focal spike activity and global $\left[{ }^{18} \mathrm{~F}\right] \mathrm{GE}-179$ uptake. Moreover, it would be oversimplistic to assume a linear relation between global $\left[{ }^{18} \mathrm{~F}\right] \mathrm{GE}-179 \mathrm{~V}_{\mathrm{T}}$ and IED frequency. We expect that NMDA receptors involved in generation of the IED would rapidly internalise ${ }^{45-47}$ or desensitise following their activation. ${ }^{4-50}$ Individual short IEDs would be very difficult to visualise over a 90 min PET scan with $\left[{ }^{18} \mathrm{~F}\right] \mathrm{GE}-179$. We assume any observed increase of $\left[{ }^{18} \mathrm{~F}\right] \mathrm{GE}-179$ binding to be related to underlying generalised baseline overactivity, rather than to transient NMDA channel opening over a few milliseconds.

In the only other in vivo PET study of NMDA ion channel activity in epilepsy, Kumlien ${ }^{51}$ did not detect focal increases in receptor availability using (S)-[N-methyl- $\left.{ }^{11} \mathrm{C}\right]$ ketamine.

Table 3 Focal increases in $\left[{ }^{18} \mathrm{~F}\right] \mathrm{GE}-179 \mathrm{~V}_{\mathrm{T}}$-individual patients versus 10 controls

\begin{tabular}{|c|c|c|c|c|c|c|c|}
\hline Patient ID & $\begin{array}{l}\text { Probable localisation } \\
\text { (EEG) }\end{array}$ & MRI & $\begin{array}{l}{\left[{ }^{18} \mathrm{~F}\right] \mathrm{GE}-179 \mathrm{~V}_{\mathrm{T}}} \\
\text { increases }\end{array}$ & $\begin{array}{l}\text { Cluster size } \\
\left(\mathrm{mm}^{3} / \text { voxels }\right)\end{array}$ & $\begin{array}{l}\text { Peak voxel coordinates } \\
(x, y, z ; m m)\end{array}$ & $Z_{\max }$ & $\begin{array}{l}\text { Cluster level } \\
\text { p (uncorrected) }\end{array}$ \\
\hline 1 & $L$ frontotemporal & R IFG lesion & $L$ frontal & $7000 / 875$ & -322234 & 4.46 & $<0.001$ \\
\hline \multirow[t]{3}{*}{4} & \multirow[t]{3}{*}{ Multifocal } & \multirow[t]{3}{*}{ Multiple tubers } & Brainstem & $5152 / 644$ & $08-28-38$ & 4.58 & 0.001 \\
\hline & & & $\mathrm{L}$ temporal & $3264 / 408$ & $-32 \quad 04-36$ & 4.09 & 0.007 \\
\hline & & & $\mathrm{R}$ temporal & $1720 / 215$ & $1804-30$ & 3.97 & 0.039 \\
\hline 5 & Bilateral temporal $\mathrm{L}>\mathrm{R}$ & Negative & $R$ frontal & $3360 / 420$ & 381024 & 4.43 & 0.006 \\
\hline \multirow[t]{2}{*}{7} & \multirow[t]{2}{*}{$\mathrm{R}$ frontal } & \multirow[t]{2}{*}{ Negative } & L frontal & $5904 / 738$ & -122242 & 4.23 & 0.001 \\
\hline & & & $\mathrm{R}$ frontal & $4512 / 564$ & 061840 & 4.23 & 0.002 \\
\hline
\end{tabular}

The cluster(s) reaching significance at $p<0.05$ uncorrected are listed. The contribution of global $V_{T}$ to variance was removed by an ANCOVA by group. Underline indicates concordance between the cluster of increase and the location of the presumed epileptogenic zone, where known.

ANCOVA, analysis of covariance; $E E G$, electroencephalography; ID, identifying number; IFG, inferior frontal gyrus; L/R, left/right; mm, millimeters; MRI, magnetic resonance imaging; $\mathrm{V}_{\mathrm{T}}$, volume-of-distribution. 
Figure 2 Focal increases in $\left[{ }^{18} \mathrm{~F}\right]$ GE-179 $V_{\mathrm{T}}$ (1 vs 10 controls, $\mathrm{p}<0.001$ voxelwise uncorrected). Top row, from top-left: patient 1, patient 4; bottom row, from left: patient 5, patient 7. Images are displayed according to neurological convention (ie, 'left is left'). For simplicity, only significant clusters $(p<0.05)$ are overlaid onto a custom $\left[{ }^{18} \mathrm{~F}\right] \mathrm{GE}-179$ template. L, left; $\mathrm{R}$, right; $\mathrm{V}_{\mathrm{T}}$, volume-of-distribution.
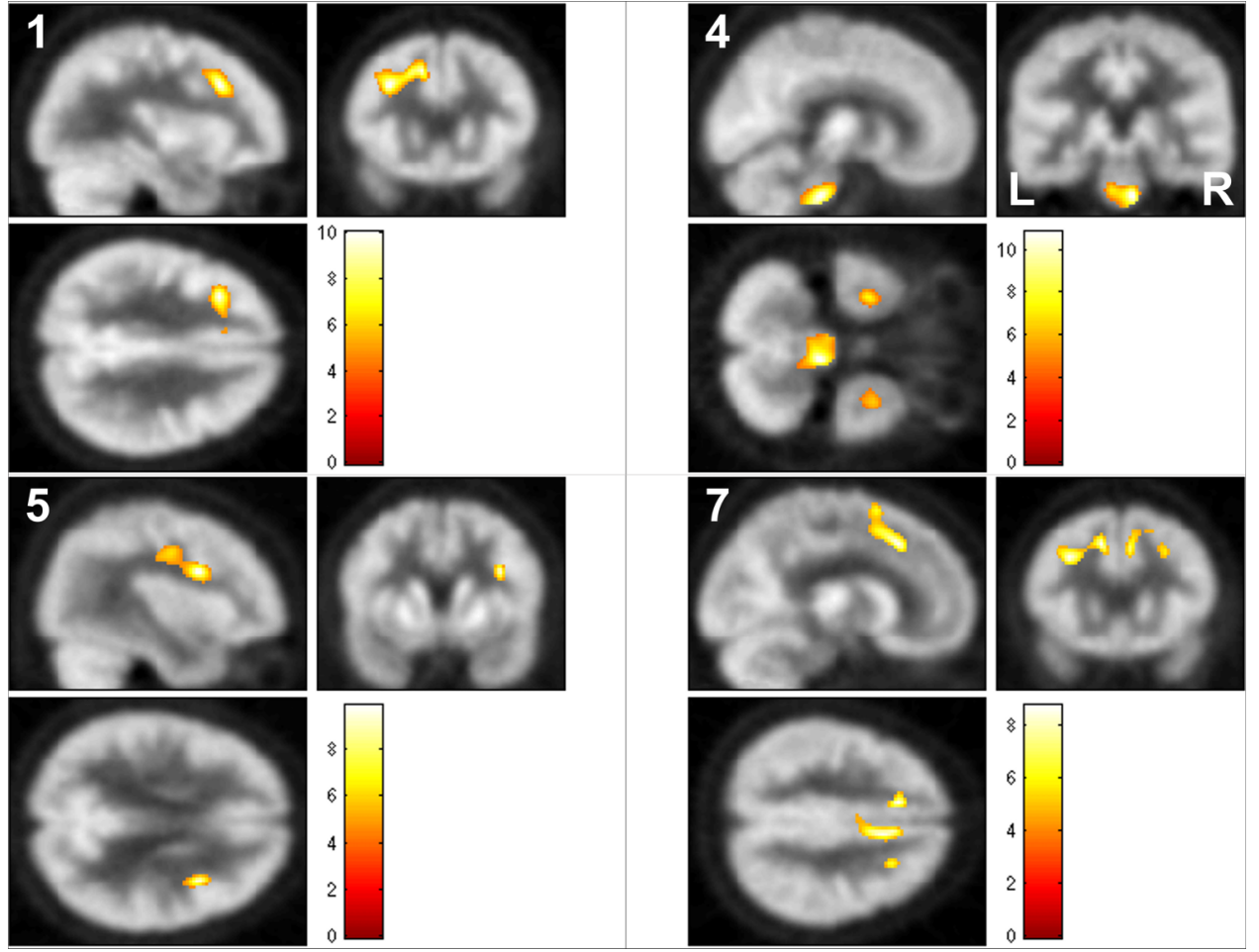

Interestingly, each participant in that temporal lobe epilepsy (TLE) cohort showed temporal hypometabolism on $\left[{ }^{18} \mathrm{~F}\right]$ FDG-PET, so the results could have been significantly confounded by cerebral hypoperfusion. Four of our patients had normal $\left[{ }^{18} \mathrm{~F}\right]$ FDG-PET, one of whom had a focal increase in $\left[{ }^{18} \mathrm{~F}\right] \mathrm{GE}-179 \mathrm{~V}_{\mathrm{T}}$. The absence of hypometabolism may have facilitated visualisation of activated NMDA receptors in our cohort. Alternatively, our cohort might have had more actively spiking cortex, and thus possibly greater NMDA receptor activation.

A striking and unanticipated finding of our study was reduced $\mathrm{V}_{\mathrm{T}}$ in the small number of patients with focal epilepsies who were taking antidepressants, suggesting that either depression or the use of antidepressant drug constituted an additional confounder. Our finding is in keeping with the mounting evidence for the action of antidepressant drugs at NMDA receptors including tricyclics ${ }^{52-56}$ and serotonin-selective reuptake inhibitors ${ }^{5455} 5758$ such as fluoxetine, ${ }^{57}$ 59-61 the two classes used by patients in this study. While our finding may represent the first in vivo evidence of an NMDA-mediated mechanism of action of antidepressants (the extent of which is likely to vary between drugs), caution is warranted as, given the sample size, the result could be due to random chance. Hence, in order to better understand $\left[{ }^{18} \mathrm{~F}\right] \mathrm{GE}-179$ binding, a larger study is required, which would compare $\left[{ }^{18} \mathrm{~F}\right] \mathrm{GE}-179$ binding between unmedicated patients with depression and those taking antidepressants. It will also be of interest to ascertain whether AEDs that are characterised by use-dependent inhibition of NMDA receptor function (such as felbamate ${ }^{62}{ }^{63}$ ), or certain combinations of AEDs, affect NMDA receptor binding.

A recent multicentre review concluded that administration of the NMDA receptor antagonist ketamine 'likely' or 'possibly' contributed to the achievement of control in 32\% of (19 of 60) episodes, whereas treatment was discontinued due to adverse events in approximately $8 \% .{ }^{64}$ Smaller series have reported greater success. ${ }^{65}{ }^{66}$ Similarly to $\left[{ }^{18} \mathrm{~F}\right] \mathrm{GE}-179,{ }^{38}$ ketamine binds to the PCP site in the NMDA ion channel pore. ${ }^{67}$ Hence, the demonstration of increased NMDA receptor activation via $\left[{ }^{18} \mathrm{~F}\right]$ GE-179 PET might aid the stratification of patients with refractory status epilepticus.

Limitations of this proof-of-principle study include the small and heterogeneous population. While $\left[{ }^{18} \mathrm{~F}\right] \mathrm{GE}-179$ has a low affinity for other CNS receptors in vitro, ${ }^{38}$ we cannot exclude the possibility that non-specific binding confounded the analyses. Further studies are needed to confirm our findings, and to quantify reproducibility and specificity of $\left[{ }^{18} \mathrm{~F}\right] \mathrm{GE}-179$ binding in vivo.

In conclusion, our results provide in vivo evidence for widespread increases in activated NMDA receptor availability in patients with focal epilepsies. A PET radioligand that reliably demonstrates focal increases in NMDA receptor activity in humans in vivo would hold potential as a method to investigate epileptogenesis in vivo after brain injury, to investigate the role of activated NMDA receptor availability in other conditions, and possibly in the presurgical investigation of patients with refractory focal epilepsy.

\section{Author affiliations}

${ }^{1}$ Division of Neuroscience, Department of Medicine, Imperial College London, London, UK

${ }^{2}$ Medical Research Council Clinical Sciences Centre, London, UK

${ }^{3}$ Division of Imaging Sciences \& Biomedical Engineering, Faculty of Life Sciences \&

Medicine, King's College London, London, UK

${ }^{4}$ Department of Clinical and Experimental Epilepsy, UCL Institute of Neurology, London, UK

${ }^{5}$ MRI Unit, Epilepsy Society, Chalfont St. Peter, UK

${ }^{6}$ The Neurodis Foundation, CERMEP Imagerie du Vivant, Lyon, France

${ }^{7}$ Department of Clinical Neurophysiology, Great Ormond Street Hospital for Children NHS Trust, London, UK

${ }^{8} \mathrm{GE}$ Healthcare plc, The Grove Centre, Amersham, UK

${ }^{9}$ National Hospital for Neurology and Neurosurgery, London, UK

${ }^{1}$ Institute of Clinical Medicine, Aarhus University, Aarhus, Denmark

Acknowledgements The authors thank the staff of Hammersmith Imanet Limited and MDx Discovery for their assistance with $\left[{ }^{18} \mathrm{~F}\right] \mathrm{GE}-179$ production and data acquisition, and similarly the radiographers of Epilepsy Society. They thank all the participants. 
Contributors CJM contributed to the design of the study, was primarily responsible for data acquisition and analysis, and prepared the manuscript drafts. MJK contributed to conceptualisation and design of the study, data review and manuscript revision. AH contributed to data analysis and review, and manuscript revision. DARB contributed to PET data acquisition and manuscript revision. RMP reported the EEG data. SL contributed to conceptualisation and design of the study, and facilitated production of the radioligand at Hammersmith Imanet Ltd. PAJ and WT contributed to conceptualisation and design of the study, data review and manuscript revision. They both also facilitated production of the radioligand at Hammersmith Imanet Ltd. CM reported on the MRIs. MRS assisted with MRI acquisition, and co-registration of MR and PET data sets. DJB contributed to conceptualisation and design of the study, submissions to regulatory bodies and manuscript review. JSD contributed to conceptualisation and design of the study, data review and manuscript revision. JSD was primarily responsible for identification of the patients with focal epilepsy.

Funding This study was supported by the Medical Research Council (MRC) Clinical Sciences Centre and GE Healthcare plc. Open access fee and colour figures fees are paid by GE Healthcare plc.

Competing interests CJM, MJK and JSD are grateful for support from the NIHR Biomedical Research Centre funding scheme to the UCLH/UCL BRC. Authors affiliated with the Division of Neuroscience, Department of Medicine, Imperial College London, London, UK, are grateful for support by the NIHR Biomedical Research Centre. SL, PAJ, WT and DJB are or were employees of GE Healthcare plc at the time of the study, which they report as a conflict of interest. CJM, JSD and MJK have received fees from GE Healthcare plc. CJM was supported by a MRC Doctoral Training Account $(3+1)$ studentship that was awarded by Imperial College London. JSD and MJK were supported by Epilepsy Society, UCL, UCL Hospitals and UCLH/UCL Biomedical Research Centre. JSD has received fees for organising symposia and lecturing for UCB Pharma, Eisai, GSK and GE Healthcare. AH was supported by an MRC Clinician Scientist Fellowship (G108/585) and by the Neurodis Foundation.

Ethics approval Royal Marsden Hospital National Health Service Research Ethics Committee.

Provenance and peer review Not commissioned; externally peer reviewed.

Data sharing statement The authors have submitted all major results from the study for publication. Unpublished data consist of individual imaging data sets and are only available to the investigators at present. Any request for data can be addressed to the corresponding author; any data sharing will be subject to restrictions based on anonymisation rules.

Open Access This is an Open Access article distributed in accordance with the Creative Commons Attribution Non Commercial (CC BY-NC 4.0) license, which permits others to distribute, remix, adapt, build upon this work non-commercially, and license their derivative works on different terms, provided the original work is properly cited and the use is non-commercial. See: http://creativecommons.org/ licenses/by-nc/4.0/

\section{REFERENCES}

1 Monaghan DT, Bridges RJ, Cotman CW. The excitatory amino acid receptors: their classes, pharmacology, and distinct properties in the function of the central nervous system. Annu Rev Pharmacol Toxicol 1989;29:365-402.

2 Wollmuth LP, Sobolevsky Al. Structure and gating of the glutamate receptor ion channel. Trends Neurosci 2004;27:321-8.

3 Leker RR, Shohami E, Leker RR, et al. Cerebral ischemia and trauma-different etiologies yet similar mechanisms: neuroprotective opportunities. Brain Res Rev 2002;39:55-73.

4 Sattler R, Xiang ZG, Lu WY, et al. Specific coupling of NMDA receptor activation to nitric oxide neurotoxicity by PSD-95 protein. Science 1999;284:1845-8.

5 Waxman EA, Lynch DR, Waxman EA, et al. N-methyl-D-aspartate receptor subtypes: multiple roles in excitotoxicity and neurological disease. Neuroscientist 2005;11:37-49.

6 Sanacora G, Treccani G, Popoli M. Towards a glutamate hypothesis of depression: an emerging frontier of neuropsychopharmacology for mood disorders. Neuropharmacology 2012;62:63-77.

7 Musazzi L, Treccani G, Mallei A, et al. The action of antidepressants on the glutamate system: regulation of glutamate release and glutamate receptors. Biol Psychiatry 2013;73:1180-8.

8 Lau CG, Zukin RS, Lau CG, et al. NMDA receptor trafficking in synaptic plasticity and neuropsychiatric disorders. Nat Rev Neurosci 2007;8:413-26.

9 Turski L, Niemann W, Stephens DN. Differential effects of antiepileptic drugs and beta-carbolines on seizures induced by excitatory amino acids. Neuroscience 1990;39:799-807.

10 Chiamulera C, Costa S, Reggiani A. Effect of NMDA- and strychnine-insensitive glycine site antagonists on NMDA-mediated convulsions and learning. Psychopharmacology (Berl) 1990;102:551-2.
11 Scerrati M, Onofrj M, Pacifici L, et al. Electrocerebral and behavioural analysis of systemic kainic acid-induced epilepsy in the rat. Drugs Exp Clin Res 1986;12:671-80

12 De Deyn PP, D'Hooge R, Marescau B, et al. Chemical models of epilepsy with some reference to their applicability in the development of anticonvulsants. Epilepsy Res 1992;12:87-110.

13 Brandt C, Potschka H, Loscher W, et al. N-methyl-D-aspartate receptor blockade after status epilepticus protects against limbic brain damage but not against epilepsy in the kainate model of temporal lobe epilepsy. Neuroscience 2003;118:727-40.

14 Anderson WW, Lewis DV, Swartzwelder HS, et al. Magnesium-free medium activates seizure-like events in the rat hippocampal slice. Brain Res 1986;398:215-19.

15 Mody I, Lambert JD, Heinemann U. Low extracellular magnesium induces epileptiform activity and spreading depression in rat hippocampal slices. J Neurophysiol 1987;57:869-88.

16 Baldino F Jr, Wolfson B, Heinemann U, et al. An N-methyl-D-aspartate (NMDA) receptor antagonist reduces bicuculline-induced depolarization shifts in neocortical explant cultures. Neurosci Lett 1986;70:101-5.

17 Uchida K. Excitatory amino acid receptors appear to mediate paroxysmal depolarizing shifts in rat neocortical neurons in vitro. Brain Res 1992;577:151-4.

18 Croucher MJ, Bradford HF, Sunter DC, et al. Inhibition of the development of electrical kindling of the prepyriform cortex by daily focal injections of excitatory amino acid antagonists. Eur J Pharmacol 1988;152:29-38.

19 Croucher MJ, Cotterell KL, Bradford HF. Competitive NMDA receptor antagonists raise electrically kindled generalized seizure thresholds. Neurochem Res 1992;17:409-13.

20 Vezzani A, Wu HQ, Moneta E, et al. Role of the N-methyl-D-aspartate-type receptors in the development and maintenance of hippocampal kindling in rats. Neurosci Lett 1988;87:63-8.

21 Savage DD, Werling LL, Nadler JV, et al. Selective increase in L-[3H]glutamate binding to a quisqualate-sensitive site on hippocampal synaptic membranes after angular bundle kindling. Eur J Pharmacol 1982;85:255-6.

22 Yeh GC, Bonhaus DW, Nadler JV, et al. N-methyl-D-aspartate receptor plasticity in kindling: quantitative and qualitative alterations in the N-methyl-D-aspartate receptor-channel complex. Proc Natl Acad Sci USA 1989;86:8157-60.

23 Geddes JW, Cahan LD, Cooper SM, et al. Altered distribution of excitatory amino acid receptors in temporal lobe epilepsy. Exp Neurol 1990;108:214-20.

24 Hosford DA, Crain BJ, Cao Z, et al. Increased AMPA-sensitive quisqualate receptor binding and reduced NMDA receptor binding in epileptic human hippocampus. J Neurosci 1991;11:428-34.

25 Louvel J, Pumain R, Avoli M, et al. GABAA inhibition controls the calcium flows during NMDA-dependent epileptiform activity in human epileptogenic neocortex. Epilepsy Res Supp/ 1996;12:293-300.

26 Cohen I, Navarro V, Clemenceau S, et al. On the origin of interictal activity in human temporal lobe epilepsy in vitro. Science 2002;298:1418-21.

27 Huberfeld G, Menendez de la Prida L, Pallud J, et al. Glutamatergic pre-ictal discharges emerge at the transition to seizure in human epilepsy. Nat Neurosci 2011;14:627-34.

28 Franck JE, Pokorny J, Kunkel DD, et al. Physiologic and morphologic characteristics of granule cell circuitry in human epileptic hippocampus. Epilepsia 1995;36:543-58.

29 Isokawa M, Fried I. Extracellular slow negative transient in the dentate gyrus of human epileptic hippocampus in vitro. Neuroscience 1996;72:31-7.

$30 \mathrm{Kim}$ YI, Peacock WJ, Dudek FE. Properties and synaptic mechanisms of bicuculline-induced epileptiform bursts in neocortical slices from children with intractable epilepsy. J Neurophysiol 1993;70:1759-66.

31 Wilson CL, Maidment NT, Shomer MH, et al. Comparison of seizure related amino acid release in human epileptic hippocampus versus a chronic, kainate rat model of hippocampal epilepsy. Epilepsy Res 1996;26:245-54.

32 Carlson $\mathrm{H}$, Ronne-Engstrom E, Ungerstedt $\mathrm{U}$, et al. Seizure related elevations of extracellular amino acids in human focal epilepsy. Neurosci Lett 1992;140:30-2.

33 During MJ, Spencer DD. Extracellular hippocampal glutamate and spontaneous seizure in the conscious human brain. Lancet 1993;341:1607-10.

34 Thomas PM, Phillips JP, O'Connor WT. Hippocampal microdialysis during spontaneous intraoperative epileptiform activity. Acta Neurochir (Wien) 2004;146:143-51.

35 Hamberger A, Nystrom B, Larsson S, et al. Amino acids in the neuronal microenvironment of focal human epileptic lesions. Epilepsy Res 1991;9:32-43.

36 Ronne-Engstrom $E$, Hillered $L$, Flink $R$, et al. Intracerebral microdialysis of extracellular amino acids in the human epileptic focus. I Cereb Blood Flow Metab 1992:12:873-6

37 Thomas PM, Phillips JP, Delanty N, et al. Elevated extracellular levels of glutamate, aspartate and gamma-aminobutyric acid within the intraoperative, spontaneously epileptiform human hippocampus. Epilepsy Res 2003;54:73-9.

38 McGinnity CJ, Hammers A, Riano Barros DA, et al. Initial evaluation of 18F-GE-179, a putative PET tracer for activated N-methyl D-aspartate receptors. J Nucl Med 2014;55:423-30.

39 Waterhouse RN, Waterhouse RN. Imaging the PCP site of the NMDA ion channel. Nucl Med Biol 2003;30:869-78.

40 Centeno M, Feldmann M, Harrison NA, et al. Epilepsy causing pupillary hippus: an unusual semiology. Epilepsia 2011;52:e93-6. 
41 Devous MD, Thisted RA, Morgan GF, et al. SPECT brain imaging in epilepsy: a meta-analysis. J Nucl Med 1998;39:285-93.

42 Kahane P, Merlet I, Gregoire MC, et al. An H(2) (15)0-PET study of cerebral blood flow changes during focal epileptic discharges induced by intracerebral electrical stimulation. Brain 1999;122(Pt 10):1851-65.

43 Lester RA, Jahr CE. NMDA channel behavior depends on agonist affinity. J Neurosci 1992;12:635-43.

44 Korinek M, Sedlacek M, Cais O, et al. Temperature dependence of N-methyl-Daspartate receptor channels and N-methyl-D-aspartate receptor excitatory postsynaptic currents. Neuroscience 2010;165:736-48.

45 Nong Y, Huang YQ, Ju W, et al. Glycine binding primes NMDA receptor internalization. Nature 2003:422:302-7.

46 Roche KW, Standley S, McCallum J, et al. Molecular determinants of NMDA receptor internalization. Nat Neurosci 2001;4:794-802.

47 Han L, Campanucci VA, Cooke J, et al. Identification of a single amino acid in GluN1 that is critical for glycine-primed internalization of NMDA receptors. Mol Brain 2013;6:36.

48 Vyklický L, Benveniste M, Mayer ML. Modulation of N-methyl-D-aspartic acid receptor desensitization by glycine in mouse cultured hippocampal neurones. J Physiol 1990;428:313-31.

49 Lin F, Stevens CF. Both open and closed NMDA receptor channels desensitize. J Neurosci 1994;14:2153-60.

50 Nahum-Levy R, Lipinski D, Shavit S, et al. Desensitization of NMDA receptor channels is modulated by glutamate agonists. Biophys $J$ 2001;80:2152-66.

51 Kumlien E. NMDA-receptor activity visualized with (S)-[N-methyl-11C]ketamine and positron emission tomography in patients with medial temporal lobe epilepsy. Epilepsia 1999;40:30-7.

52 Boyer PA, Skolnick P, Fossom LH. Chronic administration of imipramine and citalopram alters the expression of NMDA receptor subunit mRNAs in mouse brain: a quantitative in situ hybridization study. J Mol Neurosci 1998;10:219-33.

53 Tokarski K, Bobula B, Wabno J, et al. Repeated administration of imipramine attenuates glutamatergic transmission in rat frontal cortex. Neuroscience 2008:153:789-95.

54 Paul IA, Nowak G, Layer RT, et al. Adaptation of the N-methyl-D-aspartate receptor complex following chronic antidepressant treatments. J Pharmacol Exp Ther 1994;269:95-102.
55 Skolnick P, Layer RT, Popik P, et al. Adaptation of N-methyl-D-aspartate (NMDA) receptors following antidepressant treatment: implications for the pharmacotherapy of depression. Pharmacopsychiatry 1996;29:23-6.

56 Nowak G, Trullas R, Layer RT, et al. Adaptive changes in the N-methyl-Daspartate receptor complex after chronic treatment with imipramine and 1-aminocyclopropanecarboxylic acid. J Pharmacol Exp Ther 1993;265:1380-6.

57 Nowak G, Legutko B, Skolnick P, et al. Adaptation of cortical NMDA receptors by chronic treatment with specific serotonin reuptake inhibitors. Eur J Pharmacol 1998;342:367-70.

58 Ryan B, Musazzi L, Mallei A, et al. Remodelling by early-life stress of NMDA receptor-dependent synaptic plasticity in a gene-environment rat model of depression. Int I Neuropsychopharmacol 2009;12:553-9.

59 Pittaluga A, Raiteri L, Longordo F, et al. Antidepressant treatments and function of glutamate ionotropic receptors mediating amine release in hippocampus. Neuropharmacology 2007;53:27-36.

60 Musazzi L, Milanese M, Farisello P, et al. Acute stress increases depolarization-evoked glutamate release in the rat prefrontal/frontal cortex: the dampening action of antidepressants. PLOS ONE 2010;5:e8566.

61 Bonanno G, Giambelli R, Raiteri L, et al. Chronic antidepressants reduce depolarization-evoked glutamate release and protein interactions favoring formation of SNARE complex in hippocampus. J Neurosci 2005;25:3270-9.

62 Kuo CC, Lin BJ, Chang HR, et al. Use-dependent inhibition of the $\mathrm{N}$-methyl-D-aspartate currents by felbamate: a gating modifier with selective binding to the desensitized channels. Mol Pharmacol 2004;65:370-80.

63 Chang HR, Kuo CC. Characterization of the gating conformational changes in the felbamate binding site in NMDA channels. Biophys J 2007;93:456-66.

64 Gaspard N, Foreman B, Judd LM, et al. Intravenous ketamine for the treatment of refractory status epilepticus: a retrospective multicenter study. Epilepsia 2013;54:1498-503.

65 Rosati A, L'Erario M, Ilvento L, et al. Efficacy and safety of ketamine in refractory status epilepticus in children. Neurology 2012;79:2355-8.

66 Synowiec AS, Singh DS, Yenugadhati $V$, et al. Ketamine use in the treatment of refractory status epilepticus. Epilepsy Res 2013;105:183-8.

67 MacDonald JF, Bartlett MC, Mody I, et al. Actions of ketamine, phencyclidine and MK-801 on NMDA receptor currents in cultured mouse hippocampal neurones. J Physiol 1991;432:483-508. 